\title{
The Early Childhood Learning Approach in The Role Playing Center
}

\author{
Yulsyofriend \\ Early Chilhood Teacher Education Departmen, Universitas Negeri Padang \\ Padang, Indonesia
}

Corresponding e-mail: yenpgpaudfipunp@gmail.com

\begin{abstract}
Early childhood learning aims to stimulate all aspects of the development or the existing potentials in the child. in order to develop optimally and children have preparedness to face the life of their future. The purpose of early childhood education is to facilitate the growth and development of children optimally and comprehensively in accordance with the norms and values of life based on his experience. Through learning approach at the center of the role-playing of children will be able to float all his potentiality.
\end{abstract}

Keywords: $\quad$ children, learning approach, role-playing center.

\section{INTRODUCTION}

Playing activities are always fun for children. Playing for children does not just play, but it is as one part of the learning process. Playing activities can provide many stimuli to the children, in addition to making himself happy also can increase their knowledge. Children do the learning process through the life experiences. A good and enjoyable experience will have a positive impact for the children's development, and opposite. The children learns from what he sees, he hears and he feels. Children learn through playing because there is no better way that can stimulate child development except through play activities. Child learning process will run effectively if the children are feeling happy and pleasant so it will be able to provide results optimally.

Learning approaches in early childhood that appropriate will determine the success of children in achieving optimal development according to their characteristics, interests, and potential. One of learning approach applied is Center Approach or BCCT Approach (Beyond Centers and Circle Time), which is the concept of learning where teachers present the real world in the classroom and encourage students to make connections between their knowledge and application in their daily lives.

The learning approach have seven center that can be applied, namely the center of natural materials, art and creativity center, beam center, preparation center, IMTAQ (Religion) center, role play center, music and sport center. The role-playing center is a playground where learning can be developed, where children can develop imagination and express the feelings of today, yesterday and the future. The emphasis of this center depends in the storyline, so the child is accustomed to thinking systematically. Children can socialize and interact with friends and the environment, develop imaginary skills and develop children's language skills optimally.

\section{DISCUSSION}

Sujiono (2009: 42), states that the aim of early childhood education to be achieved is to develop knowledge and understanding of parents and teachers as well as parties related to early childhood education and development.

Further Suyanto (2005: 5) suggests the goals of early childhood education are:

"To develop the whole potential of the children so that later can functioned as a whole human according to the philosophy of a nation. Children can be viewed as individuals who are new to know the world. Children do not know the manners, rules, norms, ethics and things about the world. Children are also learning to communicate with others and learn to understand others. Children need to be guided in order to be able to understand things about the world and its content. Children also need to be guided to understand the various natural phenomena and can perform the skills needed to live in the community".

It can be explained that the purpose of early childhood education is to develop the full potential of the children from an early age as a preparation for their life-skill so that children are able to adapt to their environment and become quality children, where children can grow and develop according to the level of development so that children have readiness to go into an higher education.

According to Suryana (2013: 42) the learning process had been done from an early age is a very big influence for their life in the future, the formation of the children's behavior is determined at the age of 
the first five years. Adult behavior is strongly influenced by the formation of behavior in the first five years of life.

Suyadi (2010: 16), states that early childhood learning is done through the play activities prepared by educators by preparing material (content) and learning process. Early childhood learning materials are divided into 2 age groups, namely the material age from birth to 3 years and children aged 3-6 years. Meanwhile, according to Mursid (2015: 100), argued that the characteristics of early childhood learning is a learning-oriented on development should be in accordance with the child's age level, meaning that learning should be interested, the ability expected to be achieved, and challenging for children.

\subsection{Early Childhood Learning}

Early childhood learning is based on certain principles. The principle of early childhood learning according to Sujiono (2009: 90) namely 1) children as active learners; 2) children learn through sensory and senses; 3) children build their own knowledge; 4) children think through concrete objects; and 5) children learn from the environment.

Analogously with the above opinion, Trianto (2011: 73-74) states that there are several principles that must be considered in the implementation of early childhood learning :

1) Child-oriented development In doing the learning, educators need to provide activities in accordance with the stages of child development.

2) Child-oriented needs

Children at an early stage are in need learning process to optimize all aspects of their development. Learning should be based on the child's development and needs.

3) Play while learning or learning while playing Play is an approach in implementing early childhood learning. Through play the child is invited to explore, find, and utilize objects that are close to the child, so that learning becomes meaningful for the child.

4) Integrated stimulation

Stimulation should be given in an integrated manner so that all aspects of development can develop sustainably.

5) Environment is conducive

Student environments should be created in such an interesting and fun way that children always feel at home in the school environment.

6) Prioritizing thematic approach

The theme as a container introduces various concepts to know himself and the surrounding environment.

7) Active, creative, innovative, effective and fun
Active, creative, innovative, effective and fun learning process is provided by educators through interesting activities, which are able to aroused the curiosity in children.

8) Using various media and learning resources The use of various media and learning resources is intended so that children can explore with objects around the environment.

9) Develop life skills

The learning process should be directed to develop life skills through the preparation of learning environments that support the development of child-assisting abilities.

10) Utilization of information technology Utilization of information technology in learning activities is intended to encourage children to love learning.

11) Learning is democratic

The learning process in Kindergarten provides an opportunity for children to think, act, think and express freely and responsibly.

\subsection{The Beyond Centers and Circle Time (BCCT) or The Center Approach}

The Beyond Centers and Circles Time (BCCT) approach was coined by Maria Motessori who innovated and developed by the Creative Center for Childhood Research and Training in Florida, USA. In Indonesia the approach of BCCT is known as the center (sentra) approach. According Rakimahwati (2012: 36) Sentra comes from the word "center" which means "center". All materials that teachers will convey to children through planned activities need to be organized regularly, systematically and purposefully so that children can build the ability to analyze and can draw their own conclusions.

Mursid (2015: 5), stated that the basic concept of Beyond Centers and Circles Time (BCCT) in early childhood education is considered suitable for Indonesian conditions because the center approach puts the local culture first. The center and circle approach focused on the child, this is seen from its learning centered in the role-playing center and when the child is in a circle. The center approach encourages the child to develop the child's cognitive, social, emotional, moral, and psychomotor abilities through direct experience.

The center (Sentra in Indonesian) as a learning model to develop the full potential of children through various play activities can be divided into several kinds. According to the Directorate of Early Childhood Education in Rakimahwati (2012: 87-88), there are several centers that can develop all aspects of child development, among others: 1) the center of preparation to develop children's literacy experience, 2) the center of natural materials to develop the sensory experience of the motor Framework to strengthen three fingers for the preparation of writing 
as well as the introduction of science for children, 3) the center of role-playing to develop imagination and express the feelings of today, yesterday and the future, 4) the center of the beam to present the idea into the real form (building), 5 ) the center of faith and devotion to develop plural intelligence where the main activity is more focused on religious activities, 6) the center of art and creativity to create certain creations that will produce a work, 7) the center of music and culture to introduce a variety of music, especially traditional music, and Traditional games from various regions.

\subsection{Role Playing Center}

Latif, et al (2013: 130), states that the role playing center is also called symbolic play, role play, pretense, make belive, fantasy, imagination or drama.

In line with the above opinion, Rakimahwati (2012: 39) states that the centrer role-playing also called as symbolic play, role play, pretense, make belive, fantasy, imagination or drama. Play a large role using real-sized tools, while playing small roles using miniatures or imitations of the original shape of objects. Furthermore, Suryana (2013: 162), believes that micro / macro role play is a playground where children can develop imagination and express their feelings today, yesterday and the future.

\section{a. Role Playing Center Goals}

Sujiono and Bambang (2010: 89), the purpose of the role playing center is expected that children can socialize and interact with friends and their environment also develop the ability to speak optimally. Furthermore, according to Latif, et al (2013: 130), the specific purpose of role playing centers is to develop social and language interaction skills and build empathic feelings, take a spatial and affection point of view.

\section{b. The Application of Role Playing Center Learning}

Role play activities according to Latif, et al (2013: 131), are 1) playing a role that playing on their social that is close to the child, including the role of father, mother, doctor, animals and others; 2) activities through Small tools like dolls.

In line with the above opinion, Sujiono and Bambang (2010: 89), declared the role play play center consists of; 1) role playing activities performed inside and outside the room; 2) play small dramatization activities with the tools provided by teachers in groups, so that children can play with friends

Next Department of National Education (2004: 30 ), reveals that the stage of development of the role playing in early childhood consists of playing the role of mock, pretending to object, ostensibly related to the actions and circumstances, perseverance, relationships and communication..
According Asmawati (2014: 15), states that learning planning is a process to determine goals and identify the necessary requirements in learning in an effective and efficient way. The process of preparing the learning plan consists of three stages, namely 1) determination, in this case the teacher is required to identify the problem, analyze the setting (child, condition, source) and manage the tasks, responsibilities along with the learning schedule. 2) development, namely the process of determining and choosing the methods and learning resources that will be used so that children are interested to learn. 3) assessment, which is to evaluate, revise and determine the next action that will be done so that the child is more interested to follow the learning.

Some things we should consider as educators in designing learning planning, among others; 1) the characteristics of the child, 2) the concept of skills to be developed, 3) determine the objectives and benefits of the activities to be undertaken by the child, 4) determine the place according to the needs of the child, 5) the teacher acts as a facilitator, 6) limit the number of children in each center, 7) invite children to be active in playing, and 8) adding new tools and materials to the center.

It can be explained that there are some steps that must be done by the teacher in the planning of learning centers play a role, among others determine the theme and sub theme of learning, determine aspects of child development, determine the indicators of learning, preparing the daily plans program and the weekly daily plans program, determine the play activities in the center play, materials and learning media.

\subsection{Implementation of Learning Role Playing Center}

Foothold Play Center Play

According Martuti in Suyadi (2010: 315-316), there are several steps in the application of the center approach, namely :

- The environmental footing play (preparation), before the children come, the teachers prepare and organize the tools and materials.

- The experience footing before play, the foothold held before the children play, on this step the children is told to sit in a circle with the teacher and listen to how to play with the tools and materials that are available, the rules when playing and choosing friends to play.

- The foothold during the game takes place, the footing when the teacher plunges into the center area, but the teacher only as a facilitator, the motivator and the children's companion in play. Teachers are expected to collect the children's work and evaluate the children's developmental level. After five minutes to play, the teacher tells the child to finish the job. 
- The foothold after play, the foothold where the teacher and the child sit back in circles to do recalling or question and answer about the child's experience while playing.

Department of National Educaton (2004: 19), reveals the center learning of role-playing activities include as:

"1) The role of the role environment, the thing to be aware of is the initial Management of the role playing environment by calculating the playground, the game tool and the number of players. 2) Experimental experience before role-play, what teachers should give to children on an experience footing before role-play is introducing new vocabulary and role-playing, explaining role play, explaining using tools, discussing play ideas, providing opportunities for children to achieve social relations success. 3) The basis of the experience of each child's role play, the things teachers should pay attention to in terms of playing a role playing role for each child are giving time to formulate their ideas, assigning the played roles, approving the game to play, reinforcing and expanding the vocabulary, forging appropriate communication, social relationships. 4) Role of experience after role play, what teachers must pay attention to in terms of experience after playing a role is to support children to recall their play experiences and share their experiences of play, using time to tidy up as a positive learning experience through grouping, sequencing, and managing the play environment Role appropriately.

\subsection{Assessment / Evaluation of Role Playing Approach}

According to the Ministry of Education and Culture (2014: 30), Assessment the process and outcomes of Kindergarten learning activities is a process of collecting and reviewing information in a systematic, measurable, sustainable, and comprehensive manner about the growth and development that has been achieved by children over a period of time, So educators are easy to know aspects of child development that has not developed maximally.

\section{a. Assessment Objectives}

According to the Ministry of Education and Culture (2014: 30), the purpose of assessing learning activities in Kindergarten is 1) Providing information to educators and parents about the growth and development that has been achieved by children, 2) Using information obtained as feed ingredients back to educators to improve learning activities so that attitudes, knowledge, and skills develop optimally, 3) Provide input to parents to implement pengasuhandi family environment in accordance with children's learning process in school, 4) Providing input materials to relevant parties for the chain As well as to help the achievement of child development optimally.

\section{b. Assessment Techniques}

According to the Ministry of Education and Culture (2014: 30), in assessing the early childhood learning process there are several techniques that can be used, among others: 1) Observation. observation is a technique of assessment conducted during the learning activities either directly or indirectly, 2) Conversation is a evaluation technique that can be used both in guided activities and in free activities, 3) Assignment, is a evaluation technique in the form of tasks that will be done by children in a certain time 4) Performance, is a technique of assessment involving children in the form of implementation of an activity that can be observed, 5) Assessment of the work, is a technique of assessment by looking at the products produced by the child after performing an activity, 6) Anecdotal recording, is a technique of assessment performed with a special attitude and behavior to the child when a peristiwaterjadi suddenly / incidental good positi $\mathrm{F}$ or negative, 7) Portfolio, is a collection or track record of the results of activities continuously on various aspects of growth and development of children.

\section{c. Assessment Procedure}

According to the Ministry of Education and Culture (2014: 31), there are several assessment procedures for learning activities that must be mastered by teachers in Kindergarten, among others: 1) Referring to the competence and performed in line with the learning activities programmed in the daily plans program (RPPH), so that aspects will be developed In the daily plans program (RPPH) can be seen, have developed or not, 2) Record all the results of child development using assessment instruments 3) summarize all the results of child development, 4) Process summary results for one semester into a form of report and encryption by covering three competencies namely competence, knowledge and skills , 5) Formulate the descriptions objectively about the developmental and growth aspects of each child so its expected there is no arousing a wrong perception for parents or guardians in the form of Child Development Report.

Rakimahwati (2012: 100-101), reveals that the learning assessment of Beyond Center and Circle Time (BCCT), namely:

1. Assessment of the program, aims to determine the effectiveness of Early Childhood Education program's implementation. Program evaluation includes assessment of the performance of educators and managers, learning programs, group administration.

2. Assessment of the progress of child development, conducted by educators at each meeting by notes the development of children's abilities in fine motor, rough motor, language, social, cognitive and other 
aspects. In addition to recording educational progress learners can also use a child's development checklist.

\section{Conclusion}

Learning planning involves creating a semester program. Semester programs are grouped according to the theme that will be used during the first semester and second semester. The Weekly Plans program (RPPM) is prepared based on a predesigned semester program, from the weekly plans program that teachers prepare the daily plans program. Because the activities are done in the center, then the daily plans program is only made once in a round of learning themes, because children enter in the center is done by rolling. Daily planning in the center role playing appearnce as playing a role or play a drama.

Implementation of learning on the center of role playing consists of 1) arrangement of the environment. 2) Materials and activities in the center of role playing. 3) Core activities (footholds). core activities in the execution of role playing activities consist of the basic environmental footing, the foothold before play, the foothold at play, and the foothold after play. Every footing of the teacher should be able to develop various aspects of children's development.

Evaluation is done to see the aspect of development that has been achieved by the child. Assessment in early childhood education is also called as an assessment. Evaluation using observation techniques, conversation and performance

\section{References}

[1] Asmawati, Luluk. (2014). Perencanaan Pembelajaran PAUD. Bandung : PT Remaja Rosdakarya

[2] Daryanto. (2014). Pembelajaran Tematik Terpadu, Terintegrasi (Kurikulum 2013). Yogyakarta : Gava Media

[3] Depdiknas. (2004). Lebih Jauh Tentang Dapaur dan Kerumahtanggaan: Main Peran. Jakarta Timur : CCCRT

[4] Kemendikbud. (2014). Kurikulum 2013 PAUD Anak Usia 5-6 Tahun. Jakarta : Katalog Dalam Terbitan

[5] Latif, dkk. (2013). Orientasi Pendidikan Anak Usia Dini(Teori dan Aplikasi). Jakarta : Prenada Media Group

[6] Mursid. (2015). Pengembangan Pembelajaran PAUD. Bandung : PT Remaja Rosdakarya

[7] Rakimahwati. (2012). Model Pembelajaran Sambil Bermain Pada Pendidikan Anak Usia Dini. Padang : UNP Press

[8] Sujiono, Yuliani Nurani, (2009). Konsep Dasar Pendidikan Anak Usia Dini. (Cetakan Pertama). Jakarta: PT Indeks.

[9] Suryana, Dadan. (2013). Pendidikan Anak Usia Dini (Teori dan Praktik Pembelajaran). Padang : UNP Press

[10] Suyadi. (2010). Psikologi Belajar Pendidikan Anak Usia Dini. Yogyakarta : PT Pustaka Insan Madani, Anggota IKADI

[11] Suyanto, Slamet. (2005). Konsep Dasar Pendidikan Anak Usia Dini. Jakarta : Depdiknas

[12] Trianto.

(2011).

DesaianPengembanganPembelajaranTematikbagi AnakUsiaDini TK/RA danAnakUsiaKelasAwal SD/MI. Jakarta :Kencana 